IZA DP No. 5167

Estimating the Wage Elasticity of Labour Supply to a Firm: What Evidence Is There for Monopsony?

Alison L. Booth

Pamela Katic

September 2010 


\title{
Estimating the Wage Elasticity of Labour Supply to a Firm: What Evidence Is There for Monopsony?
}

\author{
Alison L. Booth \\ University of Essex, \\ Australian National University and IZA \\ Pamela Katic \\ Australian National University \\ Discussion Paper No. 5167 \\ September 2010 \\ IZA \\ P.O. Box 7240 \\ 53072 Bonn \\ Germany \\ Phone: +49-228-3894-0 \\ Fax: +49-228-3894-180 \\ E-mail: iza@iza.org
}

Any opinions expressed here are those of the author(s) and not those of IZA. Research published in this series may include views on policy, but the institute itself takes no institutional policy positions.

The Institute for the Study of Labor (IZA) in Bonn is a local and virtual international research center and a place of communication between science, politics and business. IZA is an independent nonprofit organization supported by Deutsche Post Foundation. The center is associated with the University of Bonn and offers a stimulating research environment through its international network, workshops and conferences, data service, project support, research visits and doctoral program. IZA engages in (i) original and internationally competitive research in all fields of labor economics, (ii) development of policy concepts, and (iii) dissemination of research results and concepts to the interested public.

IZA Discussion Papers often represent preliminary work and are circulated to encourage discussion. Citation of such a paper should account for its provisional character. A revised version may be available directly from the author. 


\section{ABSTRACT \\ Estimating the Wage Elasticity of Labour Supply to a Firm: What Evidence Is There for Monopsony?*}

In this paper we estimate the elasticity of the labour supply to a firm, using data from the Household, Income and Labour Dynamics in Australia (HILDA) Survey. Estimation of this elasticity is of particular interest not only in its own right but also because of its relevance to the debate about the competitiveness of labour markets. The essence of monopsonistically competitive labour markets is that labour supply to a firm is imperfectly elastic with respect to the wage rate. The intuition is that, where workers have heterogeneous preferences or face mobility costs, firms can offer lower wages without immediately losing their workforce. This is in contrast to the perfectly competitive extreme, in which the elasticity is infinite. Therefore a simple test of whether labour markets are perfectly or imperfectly competitive involves estimating the elasticity of the labour supply to a firm. We find that the Australian wage elasticity of labour supply to a firm is around 0.71 , only slightly smaller than the figure of 0.75 reported by Manning (2003) for the UK. These estimates are so far from the perfectly competitive assumption of an infinite elasticity that it would be difficult to make a case that labour markets are perfectly competitive.

JEL Classification: J42, J21, J71

Keywords: monopsony, imperfect competition, separation, labour supply elasticity

Corresponding author:

Alison L. Booth

Department of Economics

University of Essex

Wivenhoe Park, CO4 3SQ

United Kingdom

E-mail: albooth@essex.ac.uk

\footnotetext{
* We thank the editor Paul Miller and two anonymous referees for helpful comments, and the Australian Research Council for financial support under Discovery Project Grant No. DP0878205. This paper uses confidentialised unit record file from the Household, Income and Labour Dynamics in Australia (HILDA) survey. The HILDA Project, initiated and funded by the Commonwealth Department of Family and Community Services (FaCS), is managed by the Melbourne Institute of Applied Economic and Social Research (MIAESR). The findings and views reported in this paper are those of the authors and should not be attributed to either FaCS or the MIAESR.
} 


\section{Introduction}

Are labour markets competitive or are they characterised by frictions that essentially render them imperfectly competitive? This question can be addressed by estimating the elasticity of labour supply to a firm, as suggested by the dynamic monopsony framework. The essence of monopsonistically competitive or oligopsonistic labour markets is that labour supply to a firm is imperfectly elastic with respect to the wage rate. The intuition is that, where workers have heterogeneous preferences or face mobility costs, firms can offer lower wages without immediately losing their workforce. This is in contrast to the perfectly competitive extreme, in which the elasticity is infinite. Monopsony theory suggests that the lower the ability of a worker to exploit outside options and move from job to job, the further will that worker's wage be below his or her marginal product, and the greater the share of rents that employer can appropriate from the worker. In short, labour markets frictions may generate a surplus that can be appropriated by wage-setting employers. To address this question, our paper estimates the elasticity of the labour supply to a firm. We do this using data from the first seven waves of the Household, Income and Labour Dynamics in Australia (HILDA) Survey, a panel survey that started in 2001.

There are a number of reasons why labour markets might be frictional or imperfectly competitive. Two important examples include heterogenous preferences for non-wage characteristics of jobs (Bhaskar and To, 1999; Hamilton, Thisse and Zenou, 2000) or search frictions (Albrecht and Axell, 1984; Burdett and Mortensen, 1998; Manning, 2003). According to Bhaskar and To (1999), workers have idiosyncratic preferences over employment at different firms, and these preferences are private information. Thus a firm's wage offer depends on how 
much he or she believes the employee prefers working there, rather than elsewhere. To support this argument, Bhaskar and To (1999) cite various empirical studies. They then show that equilibrium implies a firm offers a wage below marginal product, where the firm's trade-off is between offering an even lower wage and an increased probability that the worker chooses to work elsewhere (see also Bhaskar, Manning and To, 2002). The dynamic monopsony models produce related predictions. It is these predictions that we investigate in the remainder of the paper.

To foreshadow our main results, we find that the Australian wage elasticity of labour supply to a firm is around 0.71 . This is only slightly smaller than the figure of 0.75 reported for the UK. In contrast, the elasticity of labour supply for the US is found by Manning (2003) to be 1.38 using the Panel Study of Income Dynamics (PSID) data and 0.68 using the National Longitudinal Survey of Youth (NLSY) data. All these estimates are so far from the perfectly competitive assumption of an infinite elasticity that it would be difficult to make a case that labour markets are perfectly competitive.

The next section of the paper outlines the model and methodology, while Section III describes the data. Section IV presents estimates of the separation elasticity and Section $V$ gives the implied elasticity of labour supply to a firm. A comparison is also made between our estimates and those obtained by Manning (2003) using comparable data for the US and the UK. Since the HILDA Survey used in our analysis is very similar in structure to the British Household Panel Survey (BHPS) and to the US Panel Study of Income Dynamics (PSID), this comparison is particularly relevant. Section VI discusses gender differences in the wage elasticity of 
separations and compares the Australian estimates with those found in the US and the UK. The final section concludes.

\section{Methodology}

In deriving empirical predictions from a dynamic monopsony model based on Burdett and Mortensen (1998), we closely follow Manning (2003: Chapter 4). Denote separation and recruitment rates respectively by:

$$
\begin{aligned}
& s(w)=\delta+\lambda[1-F(w)] \\
& R(w)=R^{u}+\lambda \iint^{w} f(x) N(x) d x
\end{aligned}
$$

Here $s(w)$ is the separation rate from a firm that pays wage $w, \delta$ is the exogenous rate at which workers leave employment for non-employment, and $\lambda$ is the arrival rate of job offers from the distribution of wage offers $F(w)$. The flow of recruits to the firm is denoted by $R(w)$, while $R^{u}$ represents recruits from non-employment and $N(w)$ is the firm's employment level. In steady state the total number of separations is equal to the number of recruits. Our estimates of the elasticity of labour supply are calculated using the two different methods described below.

\section{Method 1}

Differentiation with respect to $w$ of each of the pair of equations above, and use of the steady state condition that $s(w) N(w)=R(w)$, yields the following 


$$
\varepsilon_{s w}=-\varepsilon_{R w}
$$

which states that the separation elasticity $\varepsilon_{s w}$ equals the negative of the recruitment elasticity $\varepsilon_{R w}$. Rearrangement of the steady state condition yields $N(w)=R(w) / s(w)$. After taking logs of this, simplifying, and using (2), one obtains the following expression for the elasticity of labour supply $\varepsilon_{N w}$

$$
\varepsilon_{N w}=\varepsilon_{R w}-\varepsilon_{s w}=-2 \varepsilon_{s w}
$$

Thus estimating the separation elasticity and doubling it will provide an estimate of the elasticity of labour supply. ${ }^{2}$

\section{Method 2}

We now relax the assumption that separations to and recruitment from non-employment are not sensitive to the wage and calculate the elasticity of labour supply as a weighted average:

$$
\varepsilon_{N w}=\theta_{R} \varepsilon_{R w}^{e}+\left(1-\theta_{R}\right) \varepsilon_{R w}^{n}-\theta_{S} \varepsilon_{s w}^{e}-\left(1-\theta_{S}\right) \varepsilon_{s w}^{n}
$$

where $\varepsilon_{s w}^{e}$ and $\varepsilon_{s w}^{n}$ are the separation rates to employment and non-employment, $\varepsilon_{R w}^{e}$ and $\varepsilon_{R w}^{n}$ are the recruitment rates from employment and non-employment, $\theta_{S}$ is the share of separations to another job and $\theta_{R}$ is the share of recruits from employment. To simplify, we assume:

$$
\begin{aligned}
& \varepsilon_{s w}^{e}=-\varepsilon_{R w}^{e} \\
& \varepsilon_{s w}^{n}=-\varepsilon_{R w}^{n} \\
& \theta_{R}=\theta_{S}
\end{aligned}
$$

Thus, (4) becomes:

\footnotetext{
${ }^{2}$ Note that our equation (3) is equivalent to (4.14) in Manning (2003), while our equation (4) below is equivalent to Manning's (4.18).
} 


$$
\varepsilon_{N w}=-2 \theta_{R} \varepsilon_{s w}^{e}-2\left(1-\theta_{R}\right) \varepsilon_{s w}^{n}
$$

We will present estimates of the elasticity of labour supply calculated using both of these methods.

\section{Data}

Our data are from waves 1 to 7 of the Household, Income and Labour Dynamics in Australia (HILDA) Survey. The HILDA Survey distinguishes between employment-related and personal reasons why a respondent stopped work in the last job, with detailed reasons given in each category. It is therefore possible to differentiate between transitions that are job-to-job and those that are job to non-employment. ${ }^{3}$

The Household, Income and Labour Dynamics in Australia (HILDA) Survey is a nationally representative random-sample panel survey of private households in Australia. All members of households providing at least one interview in wave 1 formed the basis of the panel followed in each subsequent wave. The sample has been gradually extended to include new household members resulting from changes in the composition of the original households. The HILDA survey data have been collected annually in a standardised format since $2001 .^{4}$ This dataset has several advantages for our purposes. First, it is a remarkably rich source of information on education and other relevant attributes including demographics. Clearly the richer the set of

\footnotetext{
${ }^{3}$ The data also distinguish between annual job-to-job transitions that are voluntary or involuntary.

${ }^{4}$ Wave 1 included 13,969 respondents aged 15 and older distributed across 7682 households. Further details of the survey are provided in Watson (2008) and Wooden and Watson (2007).
} 
controls, the lower is unobserved heterogeneity. Second, the data trace the same individuals over time, allowing us to measure job separations and where the worker went after separation. We applied the following restrictions to the data to generate a sample of individuals who were: (i) present in two or more adjacent waves; (ii) in continuing employment (not in selfemployment or on a casual or fixed-term contract) at the first of each pair of waves; and (iii) receiving an hourly real wage $w$ in the range $1<w<100 .^{5}$ In addition, we dropped all pairs of waves in which the individual was younger than 25 or older than 55 in the second wave of the wave-pair. ${ }^{6}$ We also restricted the subsample to exclude workers who are in the armed forces, reporting over 100 working hours per week (hours are used to derive hourly wages), and fulltime students. After applying these restrictions, we obtained an estimating sample comprising 14,887 person-year observations, of which 8,106 are male and 6,781 female. Table A.1 in the Data Appendix provides details of restrictions that were applied to the data in order to obtain our estimating sample and the number of cases lost as each restriction was applied.

Table 1 presents summary statistics for the principal variables of interest. To calculate separations, we used our sample of pairs of waves containing individuals in continuous employment at time $t$, and then we checked where they were at time $t+1$. The first row displays the mean yearly job-separation rates for all forms of separation. ${ }^{7}$ The first column shows this was 0.139 for the combined sample of men and women. That is, on average every year around

\footnotetext{
${ }^{5}$ The hourly wage rate is that which is paid in the main job. To calculate this, we used the HILDA derived variables for the current weekly gross wages and salary for the main job, and for hours worked per week in the main job during the survey week (for more details, see Watson, 2008). We deflated wages to 2001 (wave 1) levels using the headline Consumer Price Index (CPI) from the Australian Bureau of Statistics.

${ }^{6}$ For example, if a person was 55 years old in wave 2 , then the pair wave1 and wave2 would be included but not the subsequent ones (wave2 and wave3), and so on.

${ }^{7}$ The data obtains detailed information only on annual transitions, although it does ask for the number of jobs between waves. Since less than $2 \%$ of our sample engaged in more than one transition between waves, we expect the biases in our estimates to be small.
} 
$13.9 \%$ of the sample of all workers in continuing jobs left that job for either another job or for non-employment. Next we disaggregate by gender. For men, the separation rate is 0.133 and for women it is slightly higher at 0.144 . The second and third rows look at separations to employment and non-employment respectively. We now see that the average separation rate each year to employment was $10.7 \%$. The male rate is slightly higher at $11.4 \%$ than the female of $9.7 \%$. Separations to non-employment are much lower, being $3.2 \%$ for men and women combined. When this is disaggregated by gender, each year just $1.9 \%$ of men move into nonemployment as compared with $4.7 \%$ of women. The difference between the male and female mean separations is presented in the last column. In all cases, the difference between these two means is statistically significant at the 5 percent level at least. Lastly, note that, conditional on job separation, around 0.77 of cases went to another job while the remainder went to nonemployment. For women, the exit rate into another job is proportionately smaller (at 0.674 ) than for men, for whom it is 0.857 .

[Insert Table 1 near here]

It is interesting that these job-separation rates from the HILDA Survey data are lower than those found in both the USA and the UK (see Manning, 2003). While the mean separation rate in Australia is just under $14 \%$, in Britain it is $19 \%$ and in the US it is $21 \%$.

Table 1 also displays means of some other relevant variables. For our sample of all employees in continuing jobs, the hourly wage rate in 2001 values was $A \$ 21.23$, while for men it was $A \$ 22.54$ and for women $A \$ 19.65$. These raw wage data indicate that Australian women in continuing jobs are earning around $87 \%$ of the male wage on average. The women in our sample are a few months older than the men, but they have just over two years less labour 
market experience and their job tenure is shorter by over one year. Finally, note from the last panel of Table 1 that each pair of years represents around the same proportion of the sample, at between $16 \%$ and $17 \%$.

\section{Estimating the wage elasticity of separation}

The instantaneous job separation rate is given as $s=e^{b x}$, where $\boldsymbol{X}_{i}$ is a vector of individual and firm characteristics, the associated parameter vector is given by $\boldsymbol{\beta}$, and $\ln \boldsymbol{w}_{i}$ is the natural logarithm of the real (2003 prices) hourly wage of individual $i$ at time $t$. Since the natural logarithm of the wage rate is included as an explanatory variable, the elasticity of the separation rate with respect to the wage is simply the coefficient to the wage.

To obtain the wage elasticity of separation, we estimate logit models of the probability of separating from a continuing job. Thus the dependent variable measures job terminations or separations from continuing employment in year $t$ to either another job or to nonwork in year $t+1$.

Assume that the two types of separation conditional on $\boldsymbol{X}$ are independent. Given this, it is straightforward to show that separations to another job or to non-employment can be estimated separately, and that is what we do in this paper. ${ }^{8}$ To estimate the elasticity of separation to another job, we use our sample of individuals who have been in continuous employment at time $t$ and the dependent variable is an indicator taking the value of one if the person leaves to another job at time $t+1$ and zero otherwise.. To estimate the elasticity of

\footnotetext{
${ }^{8}$ See Manning (2003: page 101) for a detailed exposition. This is analogous to estimation in a competing risks framework.
} 
separation to non-employment, we use the sample of individuals who have been in continuous employment at time $t$ and the dependent variable is an indicator variable taking the value of one if the person leaves to non-employment at time $t+1$ and zero otherwise. For each subsample, we compute, from the estimated coefficient to the log wages, the wage elasticity calculated at the sample mean of the explanatory variables.

The combined elasticity is the weighted average of these two elasticities, with the weight given by the fraction of separations into non-employment. ${ }^{9}$ This is Method 2 described in Section II above.

We estimate separation elasticities for three separate subsamples of data: men only, women only, and the combined sample of men and women, all as shown in Table 2. For each estimating sample we estimate three separate specifications: (i) without controls; (ii) with controls excluding job tenure; and (iii) with all controls including job tenure. First consider the estimates of the separation elasticity calculated for any exit (either to another job or to nonemployment), and presented in Panel A of Table 2. For the combined sample of men and women (see the third column), and from the first specification with no controls, the elasticity is found to be -0.425 . Once we incorporate controls (including the usual human capital measures but not job tenure), the elasticity drops to -0.361 . A one percent fall in the wage rate is associated with an increase in job separations of around one third of one percent, ceteris paribus. ${ }^{10}$ Although there are good arguments for excluding tenure from the estimation, we

\footnotetext{
${ }^{9}$ We also estimated all our models using probit regression, producing broadly similar elasticities to those reported here. Ransom and Oaxaca (2005) discuss in some detail methods of imputing the elasticity. We use the method they label as Method A.

${ }^{10}$ Controls are gender, age, experience, experience squared, number of children, and dummies for health status, non-English speaking background, marriage or cohabitation, highest educational qualification, state and urban. We
} 
present - in the last row of Panel A of Table 2 - the separation elasticity from a specification with tenure included. ${ }^{11}$ The elasticity almost halves, now becoming only $-0.211 .^{12}$

[Insert Table 2 near here]

Next consider the estimates of the separation elasticity for the separate male and female subsamples, calculated for any exit, and presented in the first two columns of Panel A. The second row of estimates, our preferred specification, shows the wage elasticity of job separation to be -0.389 for men and -0.31 for women.

Now turn to the disaggregated separation elasticities to another job and to nonemployment respectively, shown in Panels B and C of Table 2. These reveal that women are more sensitive to wages when shifting to another job than are men, but that men are more sensitive when shifting to non-employment. The finding that the female wage elasticity of separation is not significantly different from zero is striking, suggesting as it does that Australian women are making decisions to leave a continuing job entirely on nonwage considerations. However, Australian men are not.

That there is not a larger increase in separations in response to lower wages suggests that other factors are keeping workers at the firm, factors that we have not been able to control for in spite of our excellent data. Of course this is in accord with the assumptions of

also experimented with including wave and part-time dummies, but our estimates are not significantly affected by their inclusion.

${ }^{11}$ As job tenure and wages are positively correlated with one another and negatively correlated with job separations, the inclusion of job tenure will reduce the wage elasticity. In that case, why include it at all? As noted by Manning (2003), one might want to capture the possibility that higher wages affect separations both directly and indirectly through job tenure. But on the other hand, if there are seniority wage scales whereby workers advance automatically up the wage scale as the job-years roll by, an apparent relationship between separations and wages may be spurious. The inclusion of tenure captures this seniority-scale effect and hence spurious correlation of wages and employment will be removed.

12 Tenure and tenure squared are significant in all regressions (negative and positive respectively). As expected, the inclusion of job tenure always considerably reduces the estimated wage elasticity. 
much of the 'new monopsony' theory - that there are labour market frictions, search costs and non-pecuniary factors keeping workers in a job and consequently allowing the employer to extract some rents. For example, as noted in the Introduction, Bhaskar and To (1999) assume workers have idiosyncratic preferences over employment at different firms, and those preferences are private information. Thus a firm's wage offer depends on how much he/she believes the employee prefers working there rather than elsewhere. Bhaskar and To (1999) cite various empirical studies supporting the assumption that workers have heterogeneous preferences for non-wage characteristics. Bhaskar et al. (2002) further note that this assumption can usefully summarise the variety of reasons for imperfect competition in the labour market. Specifically, equilibrium implies a firm offers a wage below marginal product, where the firm's trade-off is between offering an even lower wage and an increased probability that the worker chooses to work elsewhere.

Using these elasticities of separation with respect to the wage rate, we can now impute the wage-elasticity of labour supply to the firm using Methods 1 and 2 . The results of this exercise are presented in the following section.

\section{Estimating the wage elasticity of labour supply to the firm}

To obtain the wage elasticity of the labour supply the firm faces, we use equation (3) and (6) above (Methods 1 and 2 respectively). Method 1 states that the negative of the elasticity of the labour supply is given by twice the elasticity of the steady state separation rate with respect to the wage. These results are given in Panel B of Table 3.

[Insert Table 3 near here] 
Our preferred estimates are those calculated with Method 2 and given in Panel $\mathrm{F}$ at the bottom of the table. These utilise the disaggregated separation elasticities to another job or to nonemployment, which are then weighted by their shares to construct the wage elasticity of the labour supply. For the specification which includes all the controls except job tenure, the wage elasticity of labour supply is 0.709 for the combined sample, and is 0.76 for men and 0.61 for women. ${ }^{13}$

[Insert Table 4 near here]

Our estimates from Australian data are only slightly smaller than those reported for the UK by Manning (2003: Table 4.10). Manning finds an elasticity of labour supply of 0.75 using both the British Household Panel Survey (BHPS) and the UK Labour Force Surveys (LFS), while ours is 0.71 . In contrast, his reported elasticity of labour supply for the US is 1.38 using the Panel Study of Income Dynamics (PSID) data and 0.68 using the National Longitudinal Survey of Youth (NLSY) data. Table 4 reports this comparison.

\section{Sensitivity analysis: Fixed effects logit estimates}

So far we have utilized the panel structure of the data only to identify transitions. We did this to be able to compare our estimates with those obtained by Manning (2003) using a similar methodology. However, to cater for unobserved heterogeneity that may lead to biased coefficients (if some individuals are innately more likely to change jobs) we also estimated a

\footnotetext{
${ }^{13}$ Such gender differences are consistent with other studies, although the magnitude differs. For example, Ransom and Oaxaca (2005), using US data from a chain of grocery stores, estimate elasticities of labour supply to the firm of around 2.7 for men and 1.5 for women. Barth and Dale-Olsen (2009) investigate the evidence for monopsonistic discrimination by gender, using linked employer-employee data for Norway. Their results suggest that a proportion of the gender gap might be attributable to gender differences in labour market frictions. They find elasticities of between 0.8 and 1.7 for different groups.
} 
fixed-effects logit model. This allows for correlation between the individual effect and the regressors.

Estimation of the fixed effects or conditional logit model requires that individuals are present in at least two sets of wave-pairs, which necessarily reduces the sample size. Almost half the sample is present in only one or two pairs of waves. Obviously those individuals present in only one pair (about one quarter of the sample) will be dropped from the conditional logit subsample. ${ }^{14}$ Thus our estimating subsample comprises 3624 individuals (1925 men and 1699 women) who are present in the data for between two and six pairs of waves.

The results from this conditional logit model are presented in Table 5. After controlling for fixed effects, we find that separation rates are no longer sensitive to the wage rate. Whether this is an artifact of our particulat dataset remains to be seen, as so far there has been little research in the separations literature relying on fixed effects estimation.

[Insert Table 5 near here]

However, our findings that separations are not significantly increased in response to lower wages do suggest that other factors may be keeping workers at the firm. This accords with the assumptions of much of the 'new monopsony' theory, namely that labour market frictions, search costs and non-pecuniary factors contribute to worker retention and consequently allow the employer to extract some rents.

\section{A cross-country comparison of separation elasticities by gender}

\footnotetext{
${ }^{14}$ There is considerable job stability across waves for the HILDA data. Australian workers in continuing employment do, like their British counterparts leave their jobs relatively infrequently compared with those in a country like the US (see Booth, Francesconi and Garcia-Serrano, 1999).
} 
We now briefly compare our separation elasticities obtained using the HILDA Survey data with those found by Manning (2003: Table 7.7) for the UK and the US, focusing on the gender differences. This is a particularly relevant comparison, as Manning also uses representative survey-based panel data. These elasticities are summarized in Table 6, with standard errors given in parentheses. Notice that including controls in the HILDA data reduces the estimated wage elasticity in almost all cases but by a smaller extent than BHPS.

[Insert Table 6 near here]

For the sample of men and women pooled, the elasticities for both separations to employment and non-employment are sensitive to the wage. However, contrary to the BHPS estimates, we find with HILDA that the latter is smaller than the former. Moreover, even though our estimates from the samples with men and women pooled are remarkably similar, as Table 4 indicated, there are some striking gender differences when we disaggregate by gender.

First, comparing the BHPS and HILDA estimates, we see that the British female separation elasticities to other jobs are smaller than the male in absolute terms. While we expected the absolute value of the male elasticity to be greater than the female for separations to other jobs, this was not found with the HILDA data. However the difference is not large.

Second, according to the BHPS, male and female separation elasticities to nonemployment are not so very different, although they are smaller in absolute terms for women than for men. However the HILDA estimates find a big difference. Indeed, the HILDA data suggest that, while the male elasticities of separation to non-employment are not so different to those from the BHPS, the HILDA female wage elasticities of separation to non-employment are close to zero. Indeed, as noted in Section IV, Australian women appear to make decisions 
to leave a continuing job entirely on nonwage considerations, whereas men do not. We hope to explore these gender comparisons further in our future research.

\section{Conclusions}

Are labour markets competitive or are they characterised by frictions that essentially render them imperfectly competitive? We addressed this question through estimation of the elasticity of labour supply to a firm, using the Household, Income and Labour Dynamics in Australia (HILDA) Survey, a panel survey with rich information about worker turnover as well as individual and firm-level attributes.

The essence of monopsonistically competitive or oligopsonistic labour markets is that labour supply to a firm is imperfectly elastic with respect to the wage rate. The intuition is that, where workers have heterogeneous preferences or face mobility costs, firms can offer lower wages without immediately losing their workforce. This is in contrast to the perfectly competitive extreme, in which the elasticity is infinite. Therefore a simple test of whether labour markets are perfectly or imperfectly competitive involves estimating the wage elasticity of the labour supply to a firm. We found that the Australian wage elasticity of labour supply is around 0.71 , only slightly smaller than the figure of 0.75 reported by Manning (2003) for the UK.

While in an ideal world one would prefer to estimate the wage elasticity of the labour supply to a firm using data from a natural experiment in which there is an exogenous change in an individual firm's wages, such data are extremely rare. Our estimates for Australia, in common with those from earlier research using the same modeling strategy, may well be 
downward-biased for the reasons detailed in Manning (2003). However, these estimates are so far from the perfectly competitive prediction of an infinite elasticity that it would be difficult to make a case that labour markets are perfectly competitive. It is interesting that a parallel stream of the labour economics literature, focusing on employer-provided training and the conditions under which firms will finance it, has reached a similar conclusion. ${ }^{15}$

${ }^{15}$ For overviews, see Acemoglu and Pischke (1999) and more recently Booth and Bryan (2005). 


\section{References}

Acemoglu, D. and J-S Pischke (1999), "The Structure of Wages and Investment in General Training," Journal of Political Economy 107(3), 539-572.

Albrecht, J.W., B. Axell (1984). An Equilibrium Model of Search Unemployment. Journal of Political Economy, 92 (5), 824- 840 (October).

Barth, E. and H. Dale-Olsen (2009). Monopsonistic Discrimination, Worker Turnover, and the Gender Wage Gap'. Labour Economics, 16, October, 589-597.

Bhaskar, V. and T. To (1999). 'Minimum Wages for Ronald McDonald Monopsonies: A Theory of Monopsonistic Competition', Economic Journal, 109, 455, April, 190-203.

Bhaskar, V., A. Manning and T. To (2002). 'Oligopsony and Monopsonistic Competition in Labor Markets', Journal of Economic Perspectives, 16, 155-174.

Booth, A.L., M Francesconi and C Garcia-Serrano 'Job Tenure and Job Mobility in Britain', Industrial and Labor Relations Review, 53(1), October, pp 43-70

Booth, A.L. and M. Bryan (2005). 'Testing Some Predictions of Human Capital Theory: New Training Evidence from Britain." Review of Economics and Statistics. Vol. LXXXVII (2) p391-394, May.

Burdett, Kenneth and Dale T. Mortensen (1998) "Wage Differentials, Employer Size, and Unemployment," International Economic Review, 39(2), 257-73.Hamilton, J., J-F Thisse and Y Zenou (2000). Wage Competition with Heterogeneous Workers and Firms. Journal of Labor Economics, 18 (3), 453-472.

Manning, Alan, (2003). Monopsony in Motion: Imperfect Competition in Labor Markets. Princeton Univ. Press, Princeton, NJ.

Ransom, MR and RL Oaxaca (2005). 'Sex Differences in Pay in a 'New Monopsony' Model of the Labor Market'. IZA Discussion paper No. 1870.

Watson, N. (ed.) (2008). HILDA User Manual - Release 6, Melbourne Institute of Applied Economic and Social Research, University of Melbourne.

Wooden, M. and Watson, N. (2007). 'The HILDA Survey and its Contribution to Economic and Social Research (So Far)'. Economic Record, 83, No. 261, 208-231, June. 
Table 1: Summary Statistics of Main Variables, HILDA Survey

\begin{tabular}{|c|c|c|c|c|c|c|c|}
\hline & \multicolumn{2}{|c|}{ All } & \multicolumn{2}{|c|}{ Males } & \multicolumn{2}{|c|}{ Females } & \multirow{2}{*}{$\begin{array}{c}\text { Difference } \\
(\mathrm{M}-\mathrm{F})\end{array}$} \\
\hline & Mean & St Dev & Mean & St Dev & Mean & St Dev & \\
\hline \multicolumn{8}{|l|}{ Separations } \\
\hline All separations & 0.139 & 0.346 & 0.133 & 0.34 & 0.144 & 0.352 & $-0.011 * *$ \\
\hline $\begin{array}{l}\text { Separations to } \\
\text { employment } \\
\text { Separations to }\end{array}$ & 0.107 & 0.309 & 0.114 & 0.318 & 0.097 & 0.297 & $0.017^{* * *}$ \\
\hline $\begin{array}{l}\text { non- } \\
\text { employment }\end{array}$ & 0.032 & 0.176 & 0.019 & 0.137 & 0.047 & 0.212 & $-0.028 * * *$ \\
\hline Hourly salary & 21.23 & 9.06 & 22.54 & 10.00 & 19.65 & 7.48 & $2.89 * * *$ \\
\hline \multicolumn{8}{|l|}{$\begin{array}{l}\text { Control } \\
\text { variables }\end{array}$} \\
\hline Age & 40.20 & 8.42 & 40.04 & 8.32 & 40.40 & 8.53 & $-0.36 * * *$ \\
\hline Experience & 20.34 & 9.13 & 21.32 & 9.37 & 19.16 & 8.69 & $2.16^{* * *}$ \\
\hline Tenure & 7.64 & 7.61 & 8.18 & 8.12 & 6.98 & 6.89 & $1.2 * * *$ \\
\hline \multicolumn{8}{|l|}{ Sample } \\
\hline $\begin{array}{l}\text { Sample size } \\
\text { Fraction of } \\
\text { sample from } \\
\text { each pair of } \\
\text { years: }\end{array}$ & 14,887 & & 8,106 & & 6,781 & & \\
\hline $2001-2$ & 0.169 & & 0.173 & & 0.165 & & \\
\hline $2002-3$ & 0.167 & & 0.167 & & 0.167 & & \\
\hline $2003-4$ & 0.168 & & 0.169 & & 0.168 & & \\
\hline $2004-5$ & 0.166 & & 0.167 & & 0.164 & & \\
\hline $2005-6$ & 0.164 & & 0.162 & & 0.166 & & \\
\hline 2006-7 & 0.166 & & 0.162 & & 0.17 & & \\
\hline
\end{tabular}

Notes: (1) Asterisks denote level of significance of a mean comparison t-test: $* 10 \%, * * 5 \%, * * * 1 \%$. 
Table 2: Wage Elasticities of Separation, HILDA

\begin{tabular}{|c|c|c|c|}
\hline & Males & Females & All \\
\hline \multicolumn{4}{|l|}{ A. All separations } \\
\hline Mean separation rate & 0.133 & 0.144 & 0.139 \\
\hline No controls & $-0.435 * * *(0.066)$ & $-0.41 * * *(0.081)$ & $-0.425 * * *(0.051)$ \\
\hline With controls & $-0.389 * * *(0.077)$ & $-0.31 * * *(0.097)$ & $-0.361 * * *(0.06)$ \\
\hline Tenure controls & $-0.245^{* * *}(0.081)$ & $-0.151(0.102)$ & $-0.211 * * *(0.063)$ \\
\hline \multicolumn{4}{|c|}{ B. Separations to employment } \\
\hline Mean separation rate & 0.114 & 0.097 & 0.107 \\
\hline No controls & $-0.383^{* * *}(0.072)$ & $-0.515 * * *(0.099)$ & $-0.43^{* * *}(0.059)$ \\
\hline With controls & $-0.345^{* * *}(0.085)$ & $-0.449 * * *(0.119)$ & $-0.376 * * *(0.068)$ \\
\hline Tenure controls & $-0.187 * *(0.09)$ & $-0.265 * *(0.126)$ & $-0.204 * * *(0.073)$ \\
\hline \multicolumn{4}{|c|}{ C. Separations to non-employment } \\
\hline Mean separation rate & 0.019 & 0.047 & 0.032 \\
\hline No controls & $-0.685 * * *(0.167)$ & $-0.18(0.149)$ & $-0.399 * * *(0.114)$ \\
\hline With controls & $-0.591 * * *(0.194)$ & $-0.008(0.181)$ & $-0.282 * *(0.134)$ \\
\hline Tenure controls & $-0.492 * *(0.201)$ & $-0.079(0.183)$ & $-0.207(0.137)$ \\
\hline Observations & 8,106 & 6,781 & 14,887 \\
\hline
\end{tabular}

Notes: (1) Asterisks denote level of significance: $* 10 \%, * * 5 \%, * * * 1 \%$. (2) Standard errors in parenthesis. (3) The rows headed 'no controls' only include the wage reported in the previous wave and a female dummy for the pooled regressions. The rows marked 'with controls' include health, urban, education, marital status, children, region, experience, experience squared, age bands, nonenglish speaking background, and a female dummy for the pooled regressions. The rows headed 'tenure controls' include tenure and tenure squared. 
Table 3: The Elasticity of the Labour Supply Curve, HILDA Survey

\begin{tabular}{|c|c|c|c|}
\hline & Males & Females & All \\
\hline \multicolumn{4}{|l|}{ A. Elasticity of separations (All) } \\
\hline No controls & -0.435 & -0.41 & -0.425 \\
\hline With controls & -0.389 & -0.31 & -0.361 \\
\hline With controls including tenure & -0.245 & -0.151 & -0.211 \\
\hline \multicolumn{4}{|l|}{ B. Elasticity of labour supply (Method 1) } \\
\hline No controls & 0.87 & 0.82 & 0.85 \\
\hline With controls & 0.778 & 0.62 & 0.722 \\
\hline With controls including tenure & 0.490 & 0.302 & 0.422 \\
\hline \multicolumn{4}{|l|}{ C. Elasticity of separations to employment (Table 2B) } \\
\hline No controls & -0.383 & -0.515 & -0.43 \\
\hline With controls & -0.345 & -0.449 & -0.376 \\
\hline With controls including tenure & -0.187 & -0.265 & -0.204 \\
\hline \multicolumn{4}{|l|}{ D. Elasticity of separations to non-employment (Table 2C) } \\
\hline No controls & -0.685 & -0.18 & -0.399 \\
\hline With controls & -0.591 & -0.008 & -0.282 \\
\hline With controls including tenure & -0.492 & -0.079 & -0.207 \\
\hline E. Share of separations that are to employment & 0.857 & 0.674 & 0.770 \\
\hline \multicolumn{4}{|l|}{ F. Elasticity of labour supply (Method 2) } \\
\hline No controls & 0.852 & 0.812 & 0.846 \\
\hline With controls & 0.76 & 0.61 & 0.709 \\
\hline With controls including tenure & 0.461 & 0.409 & 0.409 \\
\hline
\end{tabular}

Notes: (i) Method 1 uses the elasticity of all separations to estimate the elasticity of the labour supply curve to a firm, while Method 2 utilises the disaggregated separations to another job or to non-employment and the two elasticities are weighted by their shares to construct the elasticity of the labour supply. (ii) Controls are listed at the bottom of Table 2 . 
Table 4: Separation and Labour Suppy Elasticities: Comparing Australia with Britain and the US.

\begin{tabular}{|c|c|c|c|c|c|}
\hline \multirow[b]{2}{*}{ Dataset } & \multicolumn{2}{|c|}{ USA } & \multicolumn{2}{|c|}{ UK } & \multirow{2}{*}{$\begin{array}{l}\text { Australia } \\
\text { HILDA }\end{array}$} \\
\hline & PSID & NLSY & BHPS & LFS & \\
\hline Elasticity of separations to employment & 0.867 & 0.359 & 0.631 & 0.529 & 0.376 \\
\hline Elasticity of separations to non-employment & 0.892 & 0.85 & 0.632 & 0.578 & 0.282 \\
\hline Share of separations to employment & 0.620 & 0.78 & 0.63 & 0.56 & 0.77 \\
\hline Elasticity of labour supply curve & 1.38 & 0.68 & 0.75 & 0.75 & 0.709 \\
\hline
\end{tabular}


Table 5: Wage Elasticities of Separation, HILDA Survey (Conditional Logit estimates)

Males

Females

All

\section{A. All separations}

Mean separation rate

0.133

0.144

0.139

No controls

$-0.166(0.166)$

$0.057(0.069)$

$-0.045(0.094)$

With controls

$-0.207(0.221)$

$-0.207(0.221)$

$-0.047(0.057)$

Tenure controls

$-0.042(0.07)$

$-0.001(0.002)$

$-0.008(0.011)$

\section{B. Separations to employment}

Mean separation rate

No controls

With controls

Tenure controls

\subsection{4}

$-0.218(0.188)$

$-0.318(0.235)$

$-0.114(0.168)$
0.097

$-0.268(0.259)$

$-0.279(3.61)$

$-0.047(1.97)$
0.107

$-0.236(0.152)$

$-0.295(0.182)$

$-0.085(0.104)$

\section{Separations to non-employment}

Mean separation rate

No controls

With controls

Tenure controls

$\begin{array}{ccc}0.019 & 0.047 & 0.032 \\ 0.073(0.114) & 0.023(0.024) & 0.055(0.035) \\ & \begin{array}{c}\text { Not enough observations } \\ \text { to compute these }\end{array} & \end{array}$

Notes: (1) Asterisks denote level of significance: $* 10 \%, * * 5 \%, * * * 1 \%$. (2) Standard errors in parenthesis. (3) The rows headed 'no controls' only include the wage reported in the previous wave and a female dummy for the pooled regressions. The rows marked 'with controls' include health, urban, education, marital status, children, region, experience, experience squared, age bands, nonenglish speaking background, and a female dummy for the pooled regressions. The rows headed 'tenure controls' include tenure and tenure squared. 
Table 6: Separation and Labour Suppy Elasticities: Comparing Australia with Britain and the US.

\begin{tabular}{rcccccccc}
\hline \hline \multicolumn{3}{c}{ Males } & \multicolumn{3}{c}{ Females } & & All \\
\hline HILDA & BHPS & PSID & HILDA & BHPS & PSID & HILDA & BHPS & PSID \\
\hline
\end{tabular}

A. All Separations

\begin{tabular}{llllllllll}
\hline $\begin{array}{l}\text { Mean } \\
\text { separation } \\
\text { rate }\end{array}$ & 0.133 & No inf. & No inf. & 0.144 & No inf. & No inf. & 0.139 & 0.19 & 0.21 \\
No & -0.435 & -0.968 & -1.005 & -0.41 & -0.901 & -0.971 & -0.425 & -0.798 & -0.944 \\
controls & $(0.066)$ & $(0.058)$ & $(0.055)$ & $(0.081)$ & $(0.091)$ & $(0.034)$ & $(0.051)$ & $(0.032)$ & $(0.03)$ \\
With & -0.389 & -0.742 & -0.880 & -0.31 & -0.566 & -1.055 & -0.361 & -0.720 & -0.973 \\
controls & $(0.077)$ & $(0.078)$ & $(0.058)$ & $(0.097)$ & $(0.120)$ & $(0.045)$ & $(0.06)$ & $(0.041)$ & $(0.041)$ \\
Tenure & -0.245 & No inf. & No inf. & -0.151 & No inf. & No inf. & -0.211 & -0.503 & -0.575 \\
controls & $(0.081)$ & & & $(0.102)$ & & & $(0.063)$ & $(0.064)$ & $(0.037)$
\end{tabular}

B. Separations to employment

\begin{tabular}{|c|c|c|c|c|c|c|c|c|c|}
\hline $\begin{array}{l}\text { Mean } \\
\text { separation } \\
\text { rate }\end{array}$ & 0.114 & No inf. & No inf. & 0.097 & No inf. & No inf. & 0.107 & 0.12 & 0.12 \\
\hline $\begin{array}{l}\text { No } \\
\text { controls }\end{array}$ & $\begin{array}{l}-0.383 \\
(0.072)\end{array}$ & $\begin{array}{c}-0.914 \\
(0.079)\end{array}$ & $\begin{array}{l}-0.927 \\
(0.054)\end{array}$ & $\begin{array}{l}-0.515 \\
(0.099)\end{array}$ & $\begin{array}{c}-0.886 \\
(0.131)\end{array}$ & $\begin{array}{l}-0.744 \\
(0.042)\end{array}$ & $\begin{array}{l}-0.43 \\
(0.059)\end{array}$ & $\begin{array}{r}-0.631 \\
(0.038)\end{array}$ & $\begin{array}{l}-0.759 \\
(0.050)\end{array}$ \\
\hline $\begin{array}{l}\text { With } \\
\text { controls }\end{array}$ & $\begin{array}{l}-0.345 \\
(0.085)\end{array}$ & $\begin{array}{c}-0.753 \\
(0.107)\end{array}$ & $\begin{array}{l}-0.889 \\
(0.038)\end{array}$ & $\begin{array}{l}-0.449 \\
(0.119)\end{array}$ & $\begin{array}{c}-0.471 \\
(0.172)\end{array}$ & $\begin{array}{l}-0.936 \\
(0.055)\end{array}$ & $\begin{array}{l}-0.376 \\
(0.068)\end{array}$ & $\begin{array}{r}-0.688 \\
(0.049)\end{array}$ & $\begin{array}{l}-0.867 \\
(0.038)\end{array}$ \\
\hline $\begin{array}{l}\text { Tenure } \\
\text { controls }\end{array}$ & $\begin{array}{l}-0.187 \\
(0.09)\end{array}$ & No inf. & No inf. & $\begin{array}{l}-0.265 \\
(0.126)\end{array}$ & No inf. & No inf. & $\begin{array}{l}-0.204 \\
(0.073)\end{array}$ & $\begin{array}{r}-0.429 \\
(0.050)\end{array}$ & $\begin{array}{l}-0.450 \\
(0.042)\end{array}$ \\
\hline \multicolumn{10}{|c|}{ C. Separations to non-employment } \\
\hline $\begin{array}{l}\text { Mean } \\
\text { separation } \\
\text { rate }\end{array}$ & 0.019 & No inf. & No inf. & 0.047 & No inf. & No inf. & 0.032 & 0.07 & 0.08 \\
\hline $\begin{array}{l}\text { No } \\
\text { controls }\end{array}$ & $\begin{array}{l}-0.685 \\
(0.167)\end{array}$ & $\begin{array}{c}-1.042 \\
(0.081)\end{array}$ & $\begin{array}{l}-1.046 \\
(0.088)\end{array}$ & $\begin{array}{l}-0.18 \\
(0.149)\end{array}$ & $\begin{array}{c}-0.917 \\
(0.118)\end{array}$ & $\begin{array}{l}-1.059 \\
(0.039)\end{array}$ & $\begin{array}{l}-0.399 \\
(0.114)\end{array}$ & $\begin{array}{r}-0.916 \\
(0.048)\end{array}$ & $\begin{array}{l}-1.010 \\
(0.067)\end{array}$ \\
\hline $\begin{array}{l}\text { With } \\
\text { controls }\end{array}$ & $\begin{array}{l}-0.591 \\
(0.194)\end{array}$ & $\begin{array}{c}-0.735 \\
(0.110)\end{array}$ & $\begin{array}{l}-0.868 \\
(0.085)\end{array}$ & $\begin{array}{l}-0.008 \\
(0.181)\end{array}$ & $\begin{array}{c}-0.677 \\
(0.162)\end{array}$ & $\begin{array}{l}-1.101 \\
(0.048)\end{array}$ & $\begin{array}{l}-0.282 \\
(0.134)\end{array}$ & $\begin{array}{c}-0.632 \\
(0.066)\end{array}$ & $\begin{array}{l}-0.892 \\
(0.087)\end{array}$ \\
\hline $\begin{array}{l}\text { Tenure } \\
\text { controls }\end{array}$ & $\begin{array}{l}-0.492 \\
(0.201)\end{array}$ & No inf. & No inf. & $\begin{array}{l}-0.079 \\
(0.183)\end{array}$ & No inf. & No inf. & $\begin{array}{l}-0.207 \\
(0.137)\end{array}$ & $\begin{array}{l}-0.493 \\
(0.071)\end{array}$ & $\begin{array}{l}-0.569 \\
(0.068)\end{array}$ \\
\hline
\end{tabular}

Note: No inf. stands for no information. The BHPS and PSID estimates were obtained from Manning (2003). 